\title{
PERFORMATYWNOŚĆ JĘZYKA A POWINNOŚĆ MORALNA
}

\begin{abstract}
Streszczenie. Przedmiotem rozważań podjętych w artykule jest rola języka w tworzeniu powinności moralnej. W nawiązaniu do klasycznej teorii aktów mowy J. Austina i J. Searle’a, autorka, na przykładzie czynności obiecywania, bada, na czym polega „powinnościorodna” moc słów. Zastanawia się również, jakie warunki muszą zostać spełnione, aby określona wypowiedź nakładała na jej autora moralne zobowiązanie. Przeprowadzone analizy, obejmujące również stanowisko krytyczne wobec koncepcji Searle’a, ujawniają ograniczenia, jakie wynikają z tezy, mówiącej, że to język tworzy powinność. Odwołując się do funkcji performatywnej, jaką pełni język, możemy wyjaśnić jedynie przedmiotowy wymiar obietnicy. Zrozumienie jej podmiotowego źródła wymaga zajęcia odmiennej perspektywy badawczej.
\end{abstract}

Słowa kluczowe: performatywność, język, powinność, obietnica, John Searle, John Austin, Adolf Reinach

1. Wstęp. 2. Obietnica jako performatyw. 2.1. Warunki skutecznego obiecywania. 2.2. Dlaczego słowa rodzą powinność? 3. Obietnica jako akt społeczny. 4. Przedmiotowy i podmiotowy wymiar obietnicy. 5. Zakończenie.

\section{WSTĘP}

Zdaniem wielu myślicieli we współczesnej humanistyce mamy do czynienia z tzw. „Zwrotem performatywnym”. Zainteresowanie performansem i performatywnością wynika z przekonania, że język nie tylko przedstawia rzeczywistość, ale także ją zmienia. Badania nad performatywnością dotyczą m.in. sprawczej funkcji języka, i w nawiązaniu do klasycznej teorii aktów mowy Johna L. Austina i Johna R. Searle'a, obejmują refleksję nad znaczeniem i mocą wypowiedzi performatywnych. Próbuje się wyjaśniać, w jaki sposób język i tworzone przez niego instytucje kształtują rzeczywistość społeczną, prawną, polityczną i obyczajową, pokazując, że to właśnie poprzez język formują się relacje i role społeczne. Dla etyka 
najbardziej interesujące będzie pytanie o to, czy, a jeśli tak, to w jaki sposób, język tworzy rzeczywistość moralną. W poniższym artykule chciałabym się zastanowić nad rolą języka w kontekście powinności moralnej. Czy można powiedzieć, że to język tworzy powinność? $\mathrm{Z}$ czego wynika powinnościorodna moc słów? Jeśli tak, to jakie warunki muszą zostać spełnione, aby określona wypowiedź nakładała na jej autora moralne zobowiązanie?

\section{OBIETNICA JAKO PERFORMATYW}

Od lat 50. XX w., czyli od momentu wygłoszenia przez Johna Austina na Uniwersytecie Harvarda słynnych wykładów How to Do Things with Words, wiemy, że obok wypowiedzi konstatujących, istnieją też takie, które mają moc sprawczą. Są to tzw. performatywy. Wypowiadając je, spełniamy określone czyny, np. rozkazujemy, ostrzegamy, radzimy. Czyn z kolei stanowi podstawowy przedmiot (klasycznie rozumianej) etyki. To czyny bowiem, jako działania wolne i świadome, podlegają ocenie moralnej, czyli ocenie w kategoriach dobra i zła. Jednym z najczęściej przywoływanych przykładów performatywów, które same w sobie są właśnie czynem, jest obietnica. Osobliwość obietnicy polega na tym, że jest to czynność mowy, która tworzy zobowiązanie moralne. Oznacza to, że sprawczość wypowiedzi „Obiecuję, że...” nie ogranicza się jedynie do wykonania określonej czynności, w tym przypadku czynności obiecywania, lecz polega przede wszystkim na zaistnieniu moralnej powinności.

W związku z takim ujęciem obietnicy pojawiają się dwie podstawowe kwestie. Pierwsza z nich odnosi się do założenia, zgodnie z którym powiedzenie słowa „obiecuję” jest tożsame ze złożeniem obietnicy, innym słowy obiecywanie polega na powiedzeniu „obiecuję" ${ }^{\text {C } z y}$

1 Zauważmy różnicę między wypowiedzią „obiecuję” a „wiem”. Powiedzieć „obiecuję” to tyle, co obiecać, natomiast kiedy mówimy „wiem”, nie oznacza to jeszcze, że wiemy, lecz że uważamy, że wiemy. Por. B. Mayo, A Note on Austin's Performative Theory of Knowledge, 
zawsze jednak powiedzenie „obiecuję” oznacza złożenie obietnicy? Biorąc pod uwagę rozważania Austina, należałoby dodać: w stosownych okolicznościach. Musimy, jak wyjaśnia Austin, „uwzględnić całą sytuację, w której wygłasza się wypowiedź - (...) całość czynności mowy w całościowej sytuacji mówienia"2. W związku z tym, musimy zapytać o warunki, jakie muszą zostać spełnione, aby obietnica została złożona. Druga kwestia dotyczy relacji między złożeniem obietnicy a zaistnieniem moralnej powinności. Jak stwierdza Austin „»Obiecuję« pociąga za sobą »Powinienem«"3. Czy tak jest rzeczywiście? A jeśli tak, to z czego wynika ten związek?

Obie te kwestie stały się przedmiotem dość szczegółowych analiz Searle’a. W Czynnościach mowy stawia on wprost pytanie: „W jaki sposób złożenie obietnicy może tworzyć zobowiązanie?4”. Jego zdaniem można na nie odpowiedzieć, przytaczając regułę o postaci „X uchodzi za Y”, co w przypadku obietnicy oznacza: Powiedzenie słowa „obiecuję" uchodzi za złożenie obietnicy, czyli za zobowiązanie do określonego działania. Skąd się wzięła taka reguła? Jakie jest jej źródło? Otóż, jak tłumaczy Searle, „w przypadku czynności mowy wykonywanych w ramach języka jest sprawą konwencji (...), że wypowiedzenie danych wyrażeń $\mathrm{w}$ danych warunkach uchodzi za złożenie obietnicy”5. Konwencja jest więc urzeczywistnieniem reguły. Odpowiedź, jakiej udziela Searle, choć przekonująca, rodzi nowe wątpliwości. Znaczenie performatywów jest niewątpliwie konwencjonalne, ale zasadnicza kwestia dotyczy tego, czyje (czy raczej przez kogo uznane) konwencje są znaczące. Jak wiemy różne

Philosophical Studies: An International Journal for Philosophy in the Analytic 14(1963)1-2, $28-31$.

2 J.L. Austin, Jak działać słowami, w: Mówienie i poznawanie. Rozprawy i wykłady filozoficzne, tłum. z ang. B. Chwedeńczuk, Warszawa 1993, 598.

3 Tamże, 597.

4 J. Searle, Czynności mowy. Rozważania z filozofii języka, tłum. z ang. B. Chwedeńczuk, Warszawa 1987, 51.

5 Tamże, 54. 
społeczności, przypisują odmienne znaczenia tym samym słowom i wyrażeniom. Mamy więc do czynienia z wieloznacznością słów, istniejącą nawet w ramach jednego kręgu społeczno-kulturowego. Obok tego fundamentalnego problemu pojawiają się jeszcze inne pytania: czy mówiący musi być świadomy istnienia reguly, konstytuującej czynność obiecywania? czy powinien być zdolny do jej sformułowania? Wydaje się, że mówiący nie musi wiedzieć, że znaczenie i moc obietnicy wynika z określonej reguły konstytutywnej, ale z pewnością musi znać jej treść, tak, aby mógł świadomie wykonać czynność obiecywania. Oznacza to, że obiecywać potrafi ktoś, kto jest zdolny do wyjaśnienia znaczenia czynności, którą wykonuje, mówiąc „obiecuję”. Dlatego właśnie małe dzieci, nawet wówczas, gdy wypowiadają słowo „obiecuję”, niczego nie obiecują.

\subsection{WARUNKI SKUTECZNEGO OBIECYWANIA}

Fakt, że czynnością mowy rządzą reguły, sprawia, że możemy rozpoznać niewłaściwe zachowanie, gdyż stanowi ono złamanie przynajmniej jednej z nich. Tym samym zasadne jest pytanie o warunki, jakie muszą zostać spełnione, aby wypowiedzenie słów „Obiecuję, że...” mogło zostać uznane za wykonanie czynności obiecywania. Searle podejmuje tę kwestię i zastanawia się, ,jakie warunki są konieczne i wystarczające, by czynność obiecywania była spełniona skutecznie i niewadliwie". Wymienia i omawia dziewięć takich warunków, które można sprowadzić do kilku najważniejszych. Po pierwsze, mówiący musi użyć odpowiedniej formuły, tzn. powiedzieć „obiecuję, że...” i następnie nazwać czynność (stan lub warunek), którą zobowiązuje się spełnić lub zaniechać. Właściwa formuła zakłada, że przedmiotem obietnicy może być jedynie czynność przyszła, której mówiący będzie sprawcą. Nie można bowiem obiecać czynności minionej ani takiej, którą wykona ktoś inny. To jest tzw. reguła zawartości zdaniowej, odnosząca się do treści wypowiedzi. Ponadto składający obietnicę musi zrobić to poważnie, co oznacza, że jego wypowiedź nie może 
być pasożytnicza (jak to dzieje podczas odgrywania roli, uczenia się obcego języka, recytowania poematów itp.) ani sarkastyczna. Kolejny warunek zakłada, że przedmiotem zobowiązania musi być czynność, której ten, komu obiecujemy, chce, i my musimy być o tym przekonani. Obietnica bowiem, w przeciwieństwie do groźby, stanowi przyrzeczenie zrobienia czegoś dla kogoś, a więc czegoś, czego ten ktoś sobie życzy. Jest ona składana w takiej sytuacji, która się tego domaga. Przedmiotem obietnicy jest bowiem coś, co nie jest oczywiste, by mówiący miał w zamiarze zrobić. Wszystkie te warunki obejmują reguły przygotowawcze. Obietnica powinna spełniać także warunek szczerości, a zatem mówiący powinien mieć zamiar wykonać czynność, którą obiecuje. Znaczenie obietnicy odnosi się do intencji podjęcia zobowiązania do spełnienia określonej czynności. Dlatego składający obietnicę (zgodnie z założeniem obietnicy) chce taką intencję przekazać słuchającemu. Jest to tzw. reguła szczerości ${ }^{6}$.

Rodzi ona ważne (zwłaszcza z punktu widzenia etyki i moralności) pytanie: czy wówczas, gdy mówiący nie ma zamiaru wykonać obiecywanej czynności, mimo że podaje się za kogoś, kto posiada takie intencje, rzeczywiście składa obietnicę? Innymi słowy, czy nieszczera obietnica pozostaje ważna? Jak twierdzi Searle, obietnica stanowi wyrażenie intencji, za którą mówiący ponosi odpowiedzialność, niezależnie od tego, czy jest szczera czy nie ${ }^{7}$. Autor $C z y n n o s ́ c i$ mowy podkreśla tym samym ważną rzecz - mimo że nieszczerość powoduje pewną „skazę” na czynności obiecywania, nie uwalnia ona mówiącego od odpowiedzialności za nią. Co więcej, to jest ten rodzaj niefortunności, który rodzi negatywne oceny moralne. Zatem nieszczera obietnica nie tylko pozostaje ważna, tzn. zobowiązuje moralnie mówiącego, ale również podlega ocenie, jako czyn moralnie zły. Problem, jaki się tu pojawia, wynika z poznawczej niedostępności

6 Por. tamże, 77-82.

7 Por. tamże, 83-84. 
cudzych intencji, tzn. niemożliwości sprawdzenia szczerości. Trudno więc w konkretnym przypadku obiektywnie ocenić taki czyn.

Powiedzieliśmy do tej pory, że nieszczerość nie zmienia ważności obietnicy. W sensie moralnym, czyli w odniesieniu do zasad, nieszczera obietnica pozostaje obietnica, tzn. wykonujemy czynność obiecywania i tym samym nakładamy na siebie moralne zobowiązanie do dotrzymania danego słowa. Dodajmy jednak, że w sensie etycznym, czyli w odniesieniu do relacji z samym sobą, nieszczerość unieważnia obietnicę. Jeśli wypowiadam słowa „Obiecuję, że...”, wiedząc, że ich nie dotrzymam, tak naprawdę nie obiecuję, ponieważ nie obiecuję autentycznie ${ }^{8}$.

Warto też zapytać, czy warunkiem skutecznej obietnicy jest tylko wiara wypowiadającego w to, co mówi, czy również wiara słuchającego, że składający obietnicę rzeczywiście chce jej dotrzymać. W tym miejscu trzeba podkreślić różnicę między przekonaniem słuchającego, że składający obietnicę rzeczywiście chce jej dotrzymać a przekonaniem, że składający obietnicę jedynie wierzy, że chce jej dotrzymać. W tym ostatnim przypadku mamy do czynienia $z$ rodzajem niefortunności, który wynika $z$ tego, że adresat nie uznaje wypowiedzi za obietnicę, a zatem nie wysuwa wobec mówiącego moralnego roszczenia. Skuteczność czynności mowy, a zwłaszcza czynności illokucyjnych ${ }^{9}$, polega na tym, że odbiorca rozumie daną wypowiedź, a więc przyznaje jej takie samo znaczenie i moc, jakie chce przekazać mu mówiący. Jeśli ten warunek nie zostaje spełniony, obietnica, nawet jeśli jest zgodna z regułami, opisanymi przez

8 Przyjmuję obecny w filozofii współczesnej podział na etykę i moralność oraz przypisane im znaczenia. Rozumienie moralności jako zbioru zasad i norm, a etyki jako sfery związanej ze świadomym dążeniem do dobrego życia i troską o siebie można odnaleźć m.in. w filozofii Paula Ricoeura czy Michaela Foucault.

9 Czynności illokucyjne to takie, w których mówienie jest jednocześnie działaniem, tzn. ich skutki są tożsame z aktem mowy, np. kiedy mówię „obiecuję”, jednocześnie wykonuję czynność obiecywania. 
Searle'a, jako akt międzyosobowy pozostaje jedynie usiłowaniem czy próbą złożenia obietnicy.

Podsumowując, skuteczne i niewadliwe obiecywanie musi spełniać następujące reguły: zawartości zdaniowej, przygotowawcze i regułę szczerości. Do tej listy należy dodać tzw. regułę istotną, zgodnie, z którą wypowiedzenie obietnicy uchodzi za podjęcie zobowiązania do zrobienia tego, co się obiecuje. Jest to reguła konstytutywna, czyli taka, która tworzy czynność obiecywania, tzn. sprawia, że obietnica jest w ogóle możliwa. Ważne jest również właściwe odczytanie intencji mówiącego, czyli uznanie przez adresata, że ten, który składa obietnicę, rzeczywiście bierze na siebie moralne zobowiązanie do wykonania określonej czynności.

Nie zawsze więc powiedzenie słów „Obiecuję, że...” stanowi czynność obiecywania. Musi być spełnionych szereg warunków, aby wypowiedzenie tych słów mogło zostać uznane za obietnicę. Nasuwają się jednak pytania: dlaczego właśnie takie, a nie inne warunki muszą zostać spełnione? w jaki sposób Searle doszedł do sformułowania reguł obiecywania? Wydaje się, że reguły dotyczące możliwej treści obietnicy oraz sposobu i kontekstu jej składania nie wynikają wprost z samego znaczenia czasownika „obiecuję”, lecz z sensu obietnicy. Ten ostatni zaś ujawnia się $\mathrm{w}$ doświadczeniu, a ściśle rzecz biorąc, w sposobie, w jaki ludzie obiecują. Wymienione przez Searle'a reguły stanowią więc opis użycia języka, czyli tego, w jaki sposób ludzie posługują się słowem „obiecuję", tzn. komu, co i jak obiecują.

\subsection{DLACZEGO SŁOWA RODZĄ POWINNOŚĆ?}

Zastanówmy się teraz nad drugą kwestią, dotyczącą przejścia od wypowiedzenia słów do zaistnienia moralnej powinności. Searle wyjaśnia to przejście, podając następujący ciąg twierdzeń:

1. Jan wypowiedział słowa: „Obiecuję Ci Piotrze zapłacić 5 złotych".

2. Jan obiecał zapłacić Piotrowi 5 złotych. 
3. Jan przyjął na siebie zobowiązanie zapłacenia Piotrowi 5 złotych.

4. Jan jest zobowiązany zapłacić Piotrowi 5 złotych.

5. Jan powinien zapłacić Piotrowi 5 złotych.

Jak możliwe jest przejście od twierdzenia 1. do 5.? Otóż, jak tłumaczy Searle, w pewnych okolicznościach (gdy spełnione są opisane powyżej warunki) wypowiedzenie takich słów, jak w twierdzeniu 1. jest czynnością złożenia obietnicy. Obiecywanie jest na mocy definicji czynnością przyjmowania na siebie (lub podejmowania, uznawania, uświadamiania sobie) zobowiązania wobec tego, komu się obiecuje, iż wykona się w przyszłości określone działanie. Jeśli ktoś przyjął na siebie zobowiązanie, póki trwa zobowiązanie, jest zobowiązany. Fakt bycia zobowiązanym wynika, na mocy prawdy analitycznej, z przyjęcia na siebie zobowiązania. Nie sposób bowiem, wyjaśnia Searle, skutecznie przyjąć na siebie zobowiązania, jeśli nie ma momentu, w którym jest się zobowiązanym. A jeśli ktoś jest zobowiązany coś zrobić, powinien zrobić to, do czego jest zobowiązany. Searle zauważa jednak, że istnieje szereg okoliczności, które mogą nas uwolnić od zobowiązania. Mogą się na przykład pojawić inne zobowiązania, ważniejsze $\mathrm{w}$ sensie moralnym od tych już przyjętych, lub może się okazać, że spełnienie obietnicy przyniesie złe konsekwencje. Są to takie okoliczności, które niejako unieważniaja pierwotne zobowiązanie, tzn. w określonej sytuacji nie powinniśmy wykonywać obiecanego czynu, ponieważ ciąży na nas inne, bardziej doniosłe moralnie zobowiązanie ${ }^{10}$.

Zapytajmy teraz, na jakiej podstawie Searle dokonuje przejścia od twierdzenia 1. do 5. Jak sam tłumaczy, przesłanki potrzebne, by dokonać przejścia od wypowiedzenia określonych słów do zaistnienia powinności, nie mają charakteru przesłanek moralnych czy wartościujących, ale składają się z założeń empirycznych, tautologii i opisów użycia języka. Związek między wypowiadaniem wyrażenia

10 Por. J. Searle, Czynności mowy, dz. cyt., 220-225. 
„Obiecuję...” a czynnością mowy polegającą na obiecywaniu, opiera się na znaczeniu słowa „obiecuję", które wypowiedziane w pewnych warunkach stanowi czynność obiecywania. Określając znaczenie słowa „obiecuję" i jego użycie odwołujemy się do instytucji obiecywania, a zatem do określonej konwencji. Przekształcenie obiecywania w zobowiązanie, a następnie przejście od zobowiązania do powinności opiera się na związkach definicyjnych między „obiecywać”, „zobowiązywać” a „powinien”11. A zatem, w przekonaniu Searle’a, obowiązek dotrzymywania obietnic jest nie tyle obowiązkiem moralnym, ile wynika ze znaczenia słów „Obiecuję, że...”. Znaczenie to zaś jest związane $\mathrm{z}$ konwencją, w ramach której powiedzenie słów „obiecuję, że...” uchodzi za przyjęcie na siebie określonego zobowiązania.

Jak wyjaśnia autor Czynności mowy, „w przypadku czynności mowy wykonywanych w ramach języka jest sprawą konwencji, (...) $\dot{z} e$ wypowiedzenie danych wyrażeń $\mathrm{w}$ danych warunkach uchodzi za złożenie obietnicy"12. Można jednak zapytać: zgodnie, z jaką konwencją obietnica uchodzi za podjęcie moralnego zobowiązania? Jak pokazuje w swoim artykule pt. Czym jest obiecywanie? Mirosław Rutkowski, istnieje wiele różnych interpretacji obietnicy. Autor wyjaśnia, że obietnicę konstytuuje przynajmniej kilka własności. Obok powoływania moralnego obowiązku, wyróżnić można także takie, jak informowanie innych, że dotrzyma się danego słowa czy wyrażanie własnych intencji. Różnorodność proponowanych interpretacji nadaje obietnicy bardzo wiele znaczeń. W konsekwencji opinie na temat tego, co stanowi podstawową funkcję obiecywania, bywają rozbieżne, a nawet przeciwstawne. Czy możemy zatem jednoznacznie stwierdzić, co znaczy słowo „obiecywać”? Zauważmy też, że na gruncie niektórych definicji (D. Hume, R. Price) obietnica posiada

11 Por. tamże 226.

12 Tamże, 54. 
charakter pozamoralny ${ }^{13}$. Twierdzenie, że obiecywanie polega jedynie na wyrażaniu zamiaru zaprzecza tezie, zgodnie z którą obietnica stanowi podjęcie moralnego zobowiązania. Searle nie dostrzegał tego problemu. W jego przekonaniu konwencja (w ramach danego systemu społecznego) jednoznacznie określa znaczenie i moc czynności obiecywania. Musimy jednak dodać, że M. Rutkowski, po przeanalizowaniu kilku koncepcji obietnicy, dochodzi do podobnego, co Searle wniosku - obietnice zobowiązują moralnie ${ }^{14}$. Jak twierdzi, dowodzi tego m.in. empirycznie potwierdzony fakt zaufania do obiecującego. Wniosek ten nie unieważnia jednak problemu, postawionego w tym artykule - pytanie, czym jest obiecywanie, pozostaje nadal aktualne. Czy aktom mowy przysługuje więc ściśle określone znaczenie, wynikające z konwencji czy też są one nieuchronnie wieloznaczne? Czy istnieje jedna konwencja czy jest ich wiele? Przekonanie o konwencjonalnym źródle obietnicy zawsze będzie rodziło takie pytania.

Warto zauważyć, że trudności wynikające z przekonania Searle’a o konwencjonalnym źródle czynności mowy stają się jeszcze większe w odniesieniu do wyrażeń, które, zgodnie z teorią Austina, można traktować jako wypowiedzi performatywne lub nie, tzw. performatywów utajonych (implicit performatives). Posługując się nimi, mówiący nie dopełnia należycie procedury (tzn. nie zostaje ona „dostatecznie wyraźnie powołana”), w konsekwencji moc wypowiedzi nie jest jednoznacznie określona. Możemy zasadnie pytać: co mówiący miał na myśli? W konsekwencji podmiot nie jest zobowiązany do wzięcia danej wypowiedzi za określony performatyw, np. rozkaz czy obietnicę. Chodzi więc nie tyle o to, że słuchający nie rozumie, lecz że „nie musi rozumieć”, tzn. nie musi brać danej wypowiedzi np. za rozkaz ${ }^{15}$. Jak stwierdza Austin, dopóki wypowiedź nie ma

13 Por. M. Rutkowski, Czym jest obiecywanie?, http://etykapraktyczna.pl/katalog-etyki?task=viewlink\&link_id=1601 [dostęp: 4.12.2016].

14 Choć trzeba dodać, że zgodnie z koncepcją Searle’a zobowiązanie moralne wynika ze zobowiązania językowego.

15 Por. J.L. Austin, dz. cyt., 580-581. 
wyraźnej postaci performatywnej, ,zawsze można traktować ją jako wypowiedź nieperformatywną" ${ }^{16}$. Wypowiedzi „Będę tam” brakuje jasnej kwalifikacji, tzn. określenia, czy stanowi ona obietnicę, wyrażenie zamiaru, przewidywanie czy tylko przypuszczenie. Co za tym idzie, taka wypowiedź wymaga interpretacji, w odniesieniu do tego, jak powinna być rozumiana. Jak wyjaśnia Searle, czynność, w której brakuje wyraźnego środka wskazującego na moc illokucyjną, zostaje wykonana wówczas, gdy „kontekst i wypowiedź pokazują wyraźnie, że spełniony jest warunek istotny" 17 , tzn. że dana wypowiedź w danym kontekście uchodzi np. za podjęcie zobowiązania (obietnica) czy wyraz wdzięczności (dziękowanie). Zatem to, czy dana wypowiedź ma charakter performatywny czy nie, zależy od rzetelnej interpretacji, która musi uwzględniać cały kontekst, w którym pada wypowiedź. Konwencje, o których pisze Searle, obejmują więc nie tylko performatywy wyraźne, lecz także utajone. I to one decydują, czy i w jakich okolicznościach wypowiedź „Będę” uchodzi za złożenie obietnicy czy nie.

\section{OBIETNICA JAKO AKT SPOŁECZNY}

Wracając do najważniejszej kwestii, zapytajmy: czy wyjaśnienie zobowiązującego charakteru obietnicy, jakie przedstawia Searle, jest słuszne i wystarczające? Innymi słowy, czy to performatywność języka tłumaczy nam powinnościorodny charakter obietnicy? Przyjrzyjmy się przez chwilę odmiennej interpretacji, zaproponowanej przez niemieckiego fenomenologa (przedstawiciela tzw. fenomenologii monachijskiej i ucznia Edmunda Husserla) Adolfa Reinacha, którego uznaje się za protoplastę teorii aktów mowy. Podważa on,

16 Tamże, 608.

17 J.R. Searle, dz. cyt., 92. 
jak zauważa w swoim artykule John Crosby ${ }^{18}$, Searle'owską tezę mówiącą o związku wypowiedzi i zobowiązania. Tym samym zaprzecza on temu, iż źródłem powinności jest znaczenie słów, które wypowiadamy, składając obietnicę. Reinach twierdzi, że zarówno zobowiązaniu, jak i roszczeniu, wynikającym $\mathrm{z}$ aktu obietnicy przysługuje osobliwy sposób istnienia. Nie mają one ani fizycznego, ani psychicznego charakteru. Również przyczynowości aktu obietnicy (czyli wywoływania przez niego określonych skutków: moralnych zobowiązań i roszczeń) nie można uznać za naturalną, czyli taką, w której z efektu możemy wnioskować o przyczynie. W przypadku obietnicy bowiem nie mamy w ogóle możliwości dostrzec efektu, czyli zobowiązania i roszczenia w oderwaniu od aktu obiecania. Osobliwość obietnicy, obejmująca przede wszystkim specyficzną normatywność, jaka jej przysługuje, wynika w przekonaniu Reinacha $\mathrm{z}$ tego, że jest to akt społeczny. Jak każdy taki akt stanowi ona określone działanie osoby (w przeciwieństwie do doznania), które dodatkowo wymaga zewnętrznej ekspresji, najczęściej użycia słów. Nie można (i tu zgadza się z Searle’em) złożyć obietnicy jedynie $\mathrm{w}$ ramach wewnętrznego aktu, intencji, która nie zostaje wyrażona w języku, podobnie, jak nie można zadać pytania, poprosić o coś czy oskarżyć kogoś bez użycia słów. Obietnica, tłumaczy Reinach, nie może być spełniona wewnętrznie, ponieważ jako akt społeczny jest skierowana do innego (it addresses another). Istotą każdego aktu społecznego jest właśnie to, że osoba zwraca się do drugiej osoby. Dlatego warunkiem spełnienia obietnicy (podobnie jak każdego aktu

18 Sięgam do artykułu J. Crosby'ego, Speech act theory and phenomenology, w: Speech Acts, Meaning and Intentions. Critical Approaches to the Philosophy of John R. Searle, red. A. Burkhardt, Berlin, New York 1990, 62-88, ponieważ dokonuje on w nim ciekawego zestawienia poglądów Searle’a i Reinacha na interesujący nas temat, tzn. źródła zobowiązującego charakteru obietnicy. Interpretuje koncepcję niemieckiego fenomenologa, ze względu na jej zgodność z teorią Searle’a, tzn. przyjmując punkt widzenia Reinacha, wchodzi w polemikę z autorem Czynności mowy. Taki sposób prezentacji poglądów niemieckiego fenomenologa, pozwala spojrzeć na koncepcję Searla z perspektywy, która umożliwia dostrzeżenie zarówno jej mocnych, jak i słabych stron. 
illokucyjnego w koncepcji Searle’a i Austina) jest to, że musi być usłyszana i zrozumiana. Stąd wymóg uzewnętrznienia wewnętrznej intencji spełnienia obiecanej czynności. Podkreślmy jednak, że owa wypowiedź „Obiecuję” nie stanowi opisu owego wewnętrznego aktu, lecz sama jest złożeniem obietnicy. Reinach jest przekonany, że w przypadku obiecywania mamy do czynienia z jednym aktem, który posiada swój wymiar wewnętrzny i zewnętrzny, a nie, jak sądzi Searle $-z$ połączeniem wewnętrznej intencji z jednej strony i językowej wypowiedzi, która realizuje ów zamiar, $\mathrm{z}$ drugiej.

Zdaniem Crosby'ego, Reinach uznałby, że warunki szczerego i niewadliwego złożenia obietnicy wyróżnione przez Searle’a nie dotyczą w istocie aktu obietnicy jako takiego. Nie uwzględniają one bowiem jej istoty, która polega na zwróceniu się do osoby, której ją składamy. Warunki i reguły obiecywania, o których pisze Searle, nie uzasadniają, zdaniem Crosby'ego, tworzenia moralnego zobowiązania i roszczenia. Przyczyną słabości Searle’owskiej koncepcji jest, jak argumentuje, błąd, który polega na tym, że autor Czynności mowy poszukuje skuteczności obiecywania na zewnątrz aktu obietnicy - w systemie reguł konstytutywnych, które tworzą tzw. fakty instytucjonalne ${ }^{19}$. Reinach, jak sądzi J. Crosby, nie zgodziłby się z tezą, że wszystkie akty społeczne opierają się na tego rodzaju regułach. Jest bowiem wiele takich aktów, w tym obiecywanie, które posiadają niezmienną istotę, poprzedzającą wszelkie reguły i od nich niezależną. Obietnica zdaniem Reinacha, będącego przedstawicielem fenomenologii realistycznej, jest tym, czym jest nie na mocy regul, lecz samej swej istoty. Tym samym nie jest i nie może być faktem instytucjonalnym, ponieważ nie jest czymś wynalezionym. W przeciwieństwie do reguł gier, ustanowionych $\mathrm{w}$ efekcie arbitralnego aktu, prawa dotyczące obiecywania wynikają z tego, czym w swej

19 Fakty instytucjonalne zdaniem Searle’a są to takie fakty, które w odróżnieniu od faktów surowych, zakładają istnienie określonych instytucji ludzkich, np. możliwość poślubienia kogoś jest uwarunkowana istnieniem instytucji małżeństwa. Por. J. Searle, dz. cyt., 71. 
istocie jest obietnica. Zdaniem Crosby'ego, obietnica, nie będąc ani faktem surowym, ani instytucjonalnym, należy do jakiegoś trzeciego rodzaju faktów. Searle, w przekonaniu Crosby'ego, przecenia ludzką zdolność działania, kiedy twierdzi, że człowiek może tworzyć strukturę podstawowych aktów społecznych. Realność i moralna siła zobowiązania płynącego $\mathrm{z}$ obietnicy jest tak wyraźna, argumentuje Crosby, że nie może być ona efektem jakichś umownych reguł. Faktom instytucjonalnym i płynącym $\mathrm{z}$ nich zobowiązaniom przysługuje bowiem zdecydowanie słabszy sposób istnienia ${ }^{20}$.

$\mathrm{Na}$ czym zatem polega słabość koncepcji Searle’a? Crosby, przywołując myśl Reinacha, odnosi się krytycznie przede wszystkim do przekonania autora Czynności mowy, zgodnie z którym obietnica jest czymś wtórnym wobec reguł, które mają charakter konwencjonalny. Jak twierdzi fenomenolog, o tym, czym jest obietnica, decyduje jej istota ${ }^{21}$. W tym sensie jest ona czymś źródłowym, istniejącym przed wszelkiego rodzaju konwencjami i regułami. Warto byłoby się zastanowić, czy warunki i reguły rządzące czynnością obiecywania, które wymienia Searle są rzeczywiście pierwotne wobec samej obietnicy, tzn. tworzą możliwość obiecywania. Czy też są to pewne prawa rządzące obietnicą, które wynikają z tego, czym w istocie jest obietnica? Choć druga $\mathrm{z}$ wymienionych możliwości wydaje się przekonująca, to przypomnijmy, że w ujęciu Searle'a obietnicę, podobnie jak inne czynności mowy tworzą reguły konstytutywne. Są to te reguły, które decydują o tym, czym jest (za co uchodzi) dany akt mowy. Tym samym stanowią one źródło znaczenia i mocy wypowiedzi. Istnienie obietnicy rozumianej jako instytucja społeczna jest więc logicznie zależne od reguł konstytutywnych.

20 Por. J.F. Crosby, Speech act theory and phenomenology, art. cyt., 62-88.

21 Tamże, 81. 


\section{PRZEDMIOTOWY I PODMIOTOWY WYMIAR OBIETNICY}

Wydaje się, że rozbieżności w interpretacji źródeł zobowiązującego charakteru obietnicy wynikają z odmiennych perspektyw badawczych, jakie przyjmują omawiani filozofowie. Searle’a interesuje rola języka w tworzeniu powinności, dlatego swoją uwagę skupia wyłącznie na językowym wymiarze obietnicy. Choć, dodajmy, język rozumie on dość szeroko - nie obejmuje on jedynie słów, ale także konteksty ich wypowiadania, konwencje, przy pomocy których tworzone są znaczenia oraz wynikające z nich zobowiązania. Natomiast Reinach jako fenomenolog zastanawia się nad istotą obietnicy, w konsekwencji odsłania jej wymiar osobowy.

Koncentrując się na znaczeniu i na mocy obietnicy, Searle skupia się na jej wymiarze przedmiotowym. Pyta o to, czym jest czynność obiecywania, czyli co robimy, mówiąc „obiecuje”, pyta o jej treść, a więc o to, co możemy obiecać, oraz o to, w jaki sposób obiecujemy. Warunki „skutecznego i niewadliwego obiecywania”, które omawia autor Czynności mowy, są w istocie odpowiedziami na te pytania. Searle'a interesuje więc niejako „techniczny” wymiar wykonywania czynności obiecywania. Zupełnie inny charakter mają analizy dotyczące istoty i możliwości obietnicy. Myśliciele, którzy je podejmują, przyjmują perspektywę podmiotową. Czyni tak m.in. Robert Spaemann, pokazując dlaczego obiecywać mogą tylko istoty, które są osobami. Jak tłumaczy, osobowy sposób bycia, który stanowi warunek możliwości obiecywania, wyraża się w zdolności do zdystansowania się wobec samego siebie. Tylko osoby doświadczają różnicy między tym, czym są, a tym, kim są, i dzięki niej potrafią odnieść się do własnego uposażenia jakościowego, tzn. potrafią opisać i oceniać własne cechy, zdolności, zamiary czy pragnienia. Osoba bowiem posiada pewne cechy czy właściwości, ale nimi nie jest ${ }^{22}$. Dlatego

22 Por. R. Spaemann, Osoby. O różnicy między kimś a czymś, tłum. J. Merecki, Warszawa 2001, 16. 
tylko osoba może być autentycznie wolna. Ocenia ona, jak podkreśla Harry G. Frankfurt, nie tylko rzeczy z perspektywy własnych pragnień, ale także same te pragnienia ${ }^{23}$. Zauważmy, że z punktu widzenia możliwości obiecywania jest to fundamentalna zdolność. Obiecując, decydujemy teraz, co zrobimy później, niezależnie od pragnień, samopoczucia czy nastroju. Wiąże się z tym specyficznie ludzkie doświadczenie czasu, jako czasu przeszłego, teraźniejszego i przyszłego. Jak wyjaśnia Spaemann, „przez obietnicę ludzie stają ponad swym naturalnym zanurzeniem $\mathrm{w}$ strumień czasu. Tego, co będą robić w pewnym przyszłym momencie, nie pozostawiają biegowi rzeczy, nastrojowi, stanowi świadomości, pragnieniom i priorytetom, jakie będą wówczas mieli, lecz wyprzedzają czas, rozstrzygając teraz, co zrobią lub czego zaniechają później (...)"24. Jako zobowiązanie dotyczące przyszłości, wymaga ona świadomego i aktywnego odnoszenia się do czasu. Obiecując, osoba panuje nad czasem i kształtuje go. $\mathrm{Z}$ tego powodu obietnica bywa często uznawana jako symbol tożsamości osobowej, czyli trwałości i stałości osoby w czasie.

W przeciwieństwie do Searle’a, myśliciele, którzy prowadzą analizy dotyczące osobowego sposobu bycia, zastanawiają się nad sensem obietnicy, czyli nad tym, dlaczego osoba może, potrafi, chce i powinna obiecywać. Łączą istotę obietnicy z osobowym wymiarem bycia, zarówno w perspektywie wewnątrzosobowej, jak i międzyosobowej (opartym na uznaniu bycia wśród, wobec i dla innych osób).

Ta krótka uwaga pokazuje, że są to dwie odrębne perspektywy badawcze, które się wzajemnie nie wykluczają, ale uzupełniają. Zauważmy też, że jest coś, co je łączy, mianowicie nieredukowalna rola języka w akcie obiecywania. Oznacza ona, że nie mogę podjąć zobowiązania, np. złożyć obietnicy, za pomocą środków pozajęzykowych.

23 Por. H. G. Frankfurt, Wolność woli i pojęcie osoby, tłum. z ang. J. Nowotniak, w: Filozofia moralności. Postanowienie i odpowiedzialność moralna, wyb. J. Hołówka, Warszawa 1997, 23.

24 Por. R. Spaemann, dz. cyt., 275. 
Na tym właśnie polega fundamentalna rola języka w tworzeniu powinności moralnej. Co więcej, reguły i warunki obiecywania opisane przez Searle, można (poza koncepcją autora Czynności mowy) uznać za prawa rządzące obietnicą, a nie tworzące ją. Ponadto analizy dotyczące osobowych źródeł obiecywania, wyjaśniają to, czego nie wyjaśnia Searle, tzn., dlaczego w ogóle powstała instytucja obiecywania, dlaczego rządzą nią takie, a nie inne reguły. Searle zatrzymuje się na odkryciu treści reguł, ich źródło badają natomiast myśliciele koncentrujący się na podmiocie, zdolnym do złożenia i dotrzymania obietnicy.

\section{ZAKOŃCZENIE}

Powyższe analizy stanowiły próbę wyjaśnienia roli języka w odniesieniu do zobowiązującego charakteru obietnicy. Zobaczyliśmy, że związek, jaki zachodzi między językiem a etyką, wynika m.in. $\mathrm{z}$ tego, że język jest normatywny, tzn. niektóre słowa, w określonych okolicznościach, implikują zobowiązania. Fakt ich wypowiedzenia tworzy powinność, np. wówczas, gdy mówię „obiecuję”, „przyrzekam”, „ślubuję" nakładam na siebie moralny obowiązek dotrzymania danego słowa. Powinnościorodny charakter maja jednak nie tylko performatywy wyraźne. Gdy mówię np. „zrobię to” czy „zajmę się tym", również biorę na siebie odpowiedzialność za działanie, którego się podejmuję. Dlatego właśnie możemy powiedzieć, że zobowiązujący charakter wypowiadanych przez nas słów wynika nie tyle z ich znaczenia (mówiąc „obiecuję, że cię zabiję”, nie obiecuję, ale grożę), ile z własności języka, jaką jest performatywność, czyli zdolność do zmieniania rzeczywistości. Na koniec zaznaczmy jednak, że wskazanie na znaczenie i sprawczą moc języka jako źródła moralnej powinności, wyjaśnia jedynie, czym jest czynność obiecywania, nie tłumaczy zaś etycznego sensu obietnicy i jej związku z osobowym sposobem bycia. 


\title{
BIBLIOGRAFIA
}

Austin J.L., Jak działać stowami, w: Mówienie i poznawanie. Rozprawy i wyktady filozoficzne, tłum. z ang. B. Chwedeńczuk, PWN, Warszawa 1993.

Crosby J.F., Speech act theory and phenomenology, w: Speech Acts, Meaning and Intentions. Critical Approaches to the Philosophy of John R. Searle, red. A. Burkhardt, Walter de Gruyter, Berlin, New York 1990, 62-88.

Frankfurt H.G., Wolność woli i pojęcie osoby, tłum. z ang. J. Nowotniak, w: Filozofia moralności. Postanowienie i odpowiedzialność moralna, wyb. J. Hołówka, Wydawnictwo SPACJA - Fundacja Aletheia, Warszawa 1997, 21-39.

Mayo B., A Note on Austin's Performative Theory of Knowledge, Philosophical Studies: An International Journal for Philosophy in the Analytic 14(1963)1-2, 28-31.

Rutkowski M., Czym jest obiecywanie?, http://etykapraktyczna.pl/ katalog-etyki?task=viewlink\&link_id=1601.

Searle J., Czynności mowy. Rozważania z filozofii języka, tłum. z ang. B. Chwedeńczuk, Państwowy Instytut Wydawniczy PAX, Warszawa 1987.

Spaemann R., Osoby. O różnicy między kimś a czymś, tłum. J. Merecki, Oficyna Naukowa, Warszawa 2001.

\section{PERFORMATIVITY OF LANGUAGE AND MORAL OBLIGATION}

\begin{abstract}
The topic of this paper is the role of language in creating moral obligation. Drawing upon J. Austin's and J. Searle's speech act theory, the author analyzes the power of words to create obligations by using the example of promise-making. She tries to identify the conditions that must be fulfilled for a specific utterance to make a subject morally obligated, and discusses the challenges to Searle's theory. The author concludes that the performative function of the language can only explain an object dimension of promise-making. Therefore, it is crucial to take a different research perspective to reveal its subjective source.
\end{abstract}

Keywords: performativity, language, obligation, promise, John Searle, John Austin, Adolf Reinach

KAROLINA ROZMARYNOWSKA

k.rozmarynowska@uksw.edu.pl

Uniwersytet Kardynała Stefana Wyszyńskiego w Warszawie, Instytut Filozofii

Wóycickiego 1/3, 01-938 Warszawa

DOI: 10.21697/spch.2018.54.2.14 